\title{
EPISTEMOLOGY AND METHODOLOGY OF URBAN CULTURAL TOURISM: THE CASE OF THE ARTISTIC SOCIOLOGY OF MOBILE CULTURES AND TOURISM COMMUNICATION IN URBAN SOCIAL NETWORKS
}

\author{
Pedro de Andrade
}

\begin{abstract}
The epistemological, theoretical and methodological debates that aim at scientific credibility, cannot ignore the corresponding application to the social fabric. Conversely, action should always inform reflection. This article rationally demonstrates and sensorialy exhibits the following: one of the sociological genres, Artistic Sociology, transports sociology and its scientific language, from the academia to creative extension activities such as the exhibition of sociological knowledge within urban public space, for example in the case of the art gallery. In the same way, artistic knowledge and language should contaminate sociological discussion through an innovative sensibility. This is possible through the insertion, within a sociological text, not only of images from an art exhibition, presented as 'Figures' $(1,2 \ldots \mathrm{n})$. In addition, the art exhibition itself can be understood as a social and sociological configuration that is an organic part of the very body of the traditional sociological text. Thus, a profound hybridization of knowledge is sought, which can enrich, but also subvert, both sociological debates and art exhibitions. This purpose is accomplished here by several interconnected means: an epistemological approach between Artistic Sociology and Hybridogy; the theoretical problematization of mobile cultures; the empirical field work in the context of urban communication at City 3.0 and tourism communication in the context of Tourism 3.0; and the exhibition 'New Art Fest'17, as the field for the application of innovative sociological and artistic methodological approaches. A first step was Sociological Exibition on Tourism 3.0 / Cidade 3.0, that demonstrated and showed the urban and travel knowledge, within the space of the art gallery. In a second phase, this knowledge tested through the exhibition audience, is reintroduced in a scientific journal article. Such a double research movement hybridizes and confronts, in both originary and original forms, scientific and artistic knowledge and practice.
\end{abstract}

\author{
KeYwords \\ Artistic sociology; hybridology; innovative methodological approaches; \\ mobile cultures; tourism communication
}

\begin{abstract}
Resumo
Os debates epistemológicos, teóricos e metodológicos que visam credibilidade científica não podem prescindir da correspondente aplicação ao tecido social. Inversamente, a ação deverá sempre informar a reflexão. Pretende-se neste artigo demonstrar racionalmente e mostrar sensorialmente que um dos géneros sociológicos, a Sociologia Artística, faz transbordar a Sociologia e a sua linguagem científica da academia para atividades de extensão criativas, como a exposição do saber sociológico no espaço público urbano, por exemplo no caso da galeria de arte. Do mesmo modo, o conhecimento e linguagem artísticos deverão contaminar a discussão sociológica através de uma sensibilidade inovadora. Isso é possível por intermédio da inserção, num texto sociológico, não apenas das imagens oriundas de uma exposição de arte, apresentadas enquanto Figuras $(1,2 \ldots n)$. Para além disso, a própria exposição de arte poderá ser entendida como uma configuração social e sociológica que faz parte orgânica do próprio corpo do texto
\end{abstract}


sociológico tradicional. Busca-se assim uma hibridação de saberes profunda, que poderá enriquecer, mas também subverter, tanto os debates sociológicos quanto as exposições de arte. Este propósito realiza-se aqui por diversos meios interligados: uma aproximação epistemológica entre a Sociologia Artística e a Hibridologia; a problematização teórica das culturas móveis; o trabalho de campo empírico no quadro da comunicação urbana na Cidade 3.0 e a comunicação turística no contexto do Turismo 3.0; e a exposição 'New Art Fest'17, como palco da aplicação de abordagens metodológicas sociológicas e artísticas inovadoras. Numa primeira etapa, a Exposição Sociológica sobre Turismo 3.0/Cidade 3.0 demonstrou e mostrou os saberes urbanos e da viagem, no seio do espaço da galeria de arte. Numa segunda fase, este saber testado no público da exposição é reintroduzido num artigo de revista científica. Um tal duplo movimento de pesquisa hibridiza e confronta, em moldes ao mesmo tempo originários e originais, o conhecimento e a prática científicos e artísticos.

\section{PAlavras-Chave}

Abordagens metodológicas inovadoras; comunicação do turismo; culturas móveis; hibridologia; sociologia artística

\section{INTRODUCTION: METHODOLOGIES AND SOCIOLOGICAL INNOVATION}

This article simply aims to present a work in progress in the transversal scientific field of methodology, which hybridises theoretical reflection with practical application of knowledge, procedures and utensils, both classical and experimental. In particular, current methodologies have creolised the nature of modern science with the potential of post-modern resources or those inherent to advanced modernity, such as modes of digital production, since the early 1990s, in the wake of the emergence of new interactive technologies and the Internet. One of these recent research tools is online knowledge, which has been given a new lease of life not just within social media, such as Facebook, but also at the heart of the social and semantic media of the Web 3.0 or the Semantic Web. Websites and other Web 3.0 resources stand out because they focus on the production and sharing of knowledge and not just information, as Gilbert Paquette comments: "How can we make the Web more useful, more intelligent and more knowledge intensive to fulfil our demanding learning and working needs?" (Paquette, 2010, p. xiii).

This paper looks at some of the means and methods of producing and disseminating scientific knowledge. In particular, epistemological and theoretical thought is applied to scientific landscapes and arenas dealing with hybrid and transcultural processes. Some of the characteristics of these more recent forms of mixed knowledge (although not their only ones, of course) are their global and interactive nature, which introduces new problems associated with the epistemological, theoretical, analytical and empirical axes inherent to scientific work and research.

There are multiple consequences of this contemporary social context. One is the emergence of innovative methodologies, amidst the various modes and means of knowledge, as Patricia Leavy warns (2009, p. 18), in converging sociological research with artistic practice: "working with innovative methodologies often requires researchers to cross disciplinary boundaries, leave their comfort zones..." 
It should be noted that, from an epistemological point of view, "method" and "methodology" are distinct concepts. A methodology is a kind of grammar of methods and techniques, or other procedural activities for performing specific tasks, in processes that seek out one or more objectives of knowledge or wisdom. In other words, a methodology is a problematisation grid that includes, amongst other things, a set of wideranging epistemological and theoretical reflections on the practical modes of developing specific fields of study or types of knowledge. In other words, epistemological discussion of methodologies is not reduced to the difference between methods and techniques, neither is it confined to the dissimilarity between methodologies and methodological approaches. Nor is it limited to any other reductionist dichotomy. It is more intensely complex and involves highly varied strategies and tactics of practising science. Summarising some of these strategies and tactics, amongst other traits, methodology is based on logic or dialectics, whereas the methodological approach is shown to be procedural. The method is revealed as a regulatory activity, whereas the technique is affirmed as a form of instrumental action.

Furthermore, it is necessary to discern between the ideas and concepts of "creation", "invention" and "innovation". The former term has been used more frequently in art and literature, above all in Romanticism. "Invention" in turn is often associated with the scientific and technical discourse of modernism, which at times is blurred, somewhat unsatisfactorily, with pure or fundamental research. And "innovation" primarily signifies the application, in economic activities and the social fabric, of creation and invention linked to new technologies, increasingly in the context of new digital media.

In this paper, then, the concept of "innovation" is used in terms of the application of creativity and inventiveness by social scientists to the economic, social, political and cultural fields of contemporary society. As we shall see later, the aim is to deconstruct, but not fully replace, current epistemological and methodological positions that subscribe to a certain uncritical or even acritical attitude to inherited or acquired sociological methods and techniques.

In this order of ideas, it is important to revisit, albeit briefly, the theoretical and methodological equation that articulates chaos, causes and cases.

Confronted by the chaos that emerges on a daily basis in the heart of the social fabric, modern science has sought, above all since the 16th century, to domesticate it by applying a rational discourse and language which, amongst other explanatory procedures, has privileged research into the causes of social phenomena, linked to their effects. Besides this causalist thought and practice, modern rationalism has used case-study reflection and fieldwork that has sought to overcome the weak points of causalist thought via a more empirical and delimited approach. Recently, the post-modern or advanced modernist perspective has included theories such as "chaos theory" and methodologies which attempt to decode the very chaos underlying nature, humankind and culture itself, entities where the hybridisation process is not the exception but the rule, or one of the regularities, challenging some of our certainties about the very nature of science itself (Gleik, 2008). 
Today, scientists in general, and social scientists in particular, increasingly analyse and apply hybrid methods, i.e., those which mix, synthesise or creolise various, different and even opposing entities and procedures. For example, in the field of research, the rational is mixed with the sensitive, the quantitative is contaminated by the qualitative, and "manual" procedures profitably use digital technologies, etc.

These and other moments of disquiet within contemporary epistemology and methodology seem to prove that no methodology is eternal by scientific decree, and no manual can dictate what is natural, normal and legitimate within the context of scientific work. By contrast, today there are simultaneously critical and dialogical methodologies that seek to find meeting and re-meeting points between the modes and fashions of producing, interpreting and disseminating scientific knowledge. These are illustrations of this social, and also sociological, process.

As far as quantitative methods are concerned, for example, we are witnessing "turbulent times for survey methodology" via questionnaires, at a time when mixed methods are commonplace (Dillman, 2009, p. 9):

the development and generalised implementation of these communication technologies in recent years has meant that researchers conducting surveys have had to take extra measures to distinguish their questionnaire surveys from the countless other contacts (by post, phone, email, text message, etc.) which we each receive every day. In addition, the coupling of surveys with technological devices requires researchers to provide additional thoughts on how different populations interact with new technologies.

With regard to qualitative methods, netnography is a method that includes a set of relevant sociological and ethnographic techniques for cultural studies, e.g. for analysing and interpreting the interaction of members of online communities. For example, as Robert Kozinets $(2012$, pp. 68, 72) stresses, the nature of digital research has four key features: altered interaction, anonymity, accessibility, and archiving.

it is no wonder, then, that content analysis techniques are enjoying a renaissance in their application to the analysis of online conversations. The instant archiving of social communications present in the Internet makes this a very different context for doing ethnographic research than the context of face-to-face interaction. (Kozinets, 2012, p. 72)

As regards certain innovative methodologies in the sense explained above, i.e. understood in terms of grids or the questioning of the use of original methods or techniques, the radical design of games is symptomatic, as advocated by Mary Flanagan, amongst other authors: "whether it is their ability to stimulate participation in an Internet-connected age or their role as a platform for entertainment, intervention, authorship and subversion, computer video games - indeed all games - are highly relevant to the twenty-first-century imagination" (Flanagan, 2009, p. 251) .

One also notes that the methodology does not merely limit but is also influenced and reconstructed by the very nature of each study-object. Without providing definitive 
answers, this paper analyses the slippery slope of mobile cultures, in particular tourism cultures that operate via urban or digital social networks that should also be studied using mobile methods. In other words, we will not examine an abstract and unique methodology purely intended for academic purposes. Instead we shall talk about confronting this methodology, via extension activities in places beyond the academic world, in mobile or socially shifting terrains.

In fact, as Luc Pauwels (2006, p. 120) remarks, the representation of mobile cultures can be based on the expression, multivocality and reflexivity propagated for example by filming conducted in the framework of sociological and anthropological research, in particular that using digital technologies: "thus current digital media technology allows the further expansion of the discursive potential of film and transforms it into an even more hybrid product with more possibilities and challenges."

To illustrate these epistemological and methodological, critical and dialogical stances, we shall present here a hybrid method, known as Sociological Exhibition, shown at New Art Fest'17, a cultural event that ran from 1-30 November 2017 in the Sala do Picadeiro of the National Natural History and Science Museum in Lisbon. As we shall see below, this is a method that aims to creolise sociological knowledge with other social languages and contexts, such as artistic and literary activities. Concretely, using this hybrid method, three techniques were developed for conducting sociology in an art gallery, in close dialogue with its visitors. These techniques used a supposed scientific rationale, in connection with the alleged sensibility of the arts. In truth, both modes of knowledge use reason and sensation to a greater or lesser degree. The author also made use of more traditional sociological procedures, such as direct observation and interviews with visitors to this art institution, recorded on videos that will be subsequently transcribed, analysed and interpreted.

In short, this paper is not limited to one method or one technique. As we shall see below, artistic sociology is (essentially, if not only) an epistemological and methodological attitude; the aforementioned Sociological Exhibition is more properly a method, which in turn incorporates three techniques: sociological comics, a virtual visual survey and the virtual sociological gallery.

Finally, what one understands as stages in this process are actually something else. As referred to in the Abstract, these stages are, generally, three in number: 1) the planning of the project at the university or research centre; 2) the presentation of research instruments and interaction with the visitors to the art gallery; 3 ) the later inclusion of (partial) results in a sociological scientific review. Only in this manner can the research process always be a work in progress, and is never definitively established. Open complicity between the university and the extension activities occurs in this manner, in terms of a cycle of hybridisation that includes at least two types of miscegenation. Firstly, a socioscientific hybridisation occurs between the academic sociological context and the social context of the art gallery, as well as within the reverse socio-scientific journey. Secondly, a rational-sensitive hybridisation takes place between sociological knowledge and artistic knowledge and flavours. 


\section{ARTISTIC Sociology AND HYBRIDOLOGY}

Science as a whole, and the social sciences in particular, have witnessed numerous epistemological and methodological battles, for example regarding boundaries and points of contact. After all, transversalities and intersections are commonplace in the intricate web that joins the various scientific branches and communities of the social sciences.

To help, albeit incompletely, in the clarification of this state of affairs, we will discuss below only the fields of knowledge that we refer to in this article: visual sociology and the neighbouring terrain of artistic sociology.

As far as visual sociology is concerned, it chiefly includes study objects and methods which refer both to the visual referential reality and the subjectivities, rationalities and sensibilities of the social agents, with regard to the visual processes they observe or produce. Douglas Harper (2012), one of the founding fathers of this field, charts its essential outlines, from theoretical aspects (reflective and narrative perspectives, phenomenology, ethnomethodology, semiology) to activated empirical techniques (visual ethnography, incorporated observation, photo-documentary, photo-elicitation and photo voice, multimedia). Luc Pauwels' latest book (2017) updates the subject's theoretical and methodological position, including new types of analysis for images and multimodal processes, ethical reflection and the production and communication of educational content, while also providing a range of case studies. Gillian Rose (2016), an authority on the methodology of visual sociology, published an updated fourth edition of her book which besides covering the same themes of earlier editions, such as archive photography, documentary, audiences and ethical issues, examines new research areas, such as data analysis and past cyberspace research on websites and digital social networks.

Amongst the first Portuguese studies on urban visual culture from a sociological perspective rather than that of art criticism, the following stand out: interpretation of the style and content of the art of the Grupos Excursionistas e Jantaristas [Excursionist and Dining Groups] which are associations that promote an original genre of culture and popular tourism in urban taverns (Andrade, 1979, 1986, 1988, 1991); reflection on the works of the visual artist Alvarez, which often feature urban themes (Andrade, 1987). A qualitative step was subsequently taken through the problematisation and state of art of visual sociology, at the international level and the sociological situation in Portugal, from the perspective of a sociology of social visibilities and a sociology of the gaze (Andrade, 1995, 1997a, 1997b).

Other relevant studies on urban cultures, at times targeting their visual aspects, include analyses of folk festivals in the North of Portugal (Pinto, Ribeiro \& Durand, 2016), or the transformation of local cultures in this zone during the industrialisation period (Araújo, Cunha \& Ribeiro, 2015). From this perspective of mobile processes in contemporary society, Sales (2015) discusses the case of online access. This digital city context must be revisited in terms of the creativity of users and citizens (Zagalo \& Branco, 2015).

Artistic sociology, in turn, cannot be confused with visual sociology insofar as it is concerned with the arts in general and not just those that are conveyed visually. 
Furthermore, artistic sociology is not the same thing as the sociology of art. The latter uses art as a theme and employs scientific methodology, similar or dissimilar to other areas of sociology. Unusually, artistic sociology firstly uses artistic methods to understand social problems, albeit confronting them asynchronously or synchronously with information gathering instruments and sociological analysis. However, even if it applies artistic methods and techniques, artistic sociology is different from sociological art. This art movement was essentially founded by Hervé Fisher (1977), Fred Forest (1977) and JeanPaul Thénot (2012) in 1974, even though the name existed since 1968. Sociological art aimed to intervene critically on art and society, and also to question sociological theories and methods. It was chiefly critical of power and the mass media, using participation, provocation, simulacrum and irony.

In sum, artistic sociology, albeit separate, is linked to and hybridised with visual and art sociology, and also with sociological art, but in a contemporary society that is increasingly an incommensurable urban and digital network, and one that is above all founded on, and cast in, a hybrid form. Artistic sociology, after all, is understood as a hybrid knowledge that explores current hybrid reality and society. All of these hybrid fields of knowledge taken together are known as "hybridology" (Andrade, 2014; 2015).

For this desideratum, artistic sociology uses, amongst other instruments, the artistic hybridisation method. By mixing art techniques and genres, this method aims to describe, narrate, interpret, comprehend and explain the plural and profound nature of society, including cultural and artistic phenomena. Besides these hybrid artistic technologies, artistic sociology makes use of theories, concepts, methods and instruments of hybrid sociological reflection, for example hybrid concepts, creole terms that belong to different arts and cultures, central or peripheral, global or local. Mikhail Bakhtin (1983), in his literary criticism of works from diverse cultural origins in The dialogic imagination, uses the hybrid concept/method he names "chronotope" to express the complexity of the connection between time (cronos) and social spaces (topos), operated by disparate and at times antagonistic cultures or by polysemic literary genres. After all, where do culture and art end, and reflection on them begin?

Hybridology in general, and artistic sociology in particular, can be applied to multiple hybrid sociological study objects, of which the following are examples: the question of mobile cultures and the debate on tourism communication on urban and digital social networks.

\section{Mobile CULTURES}

In 1989, John Urry published a seminal work entitled The tourist gaze. In September 2011, the 3rd edition co-written with Jonas Larsen, entitled The tourist gaze 3.0, in the words of the authors, featured new analyses of photography and digitisation. This essay on the tourist gaze has influenced myriad studies on mobile cultures and urban and tourism mobilities, concepts also identified by John Urry $(2007,2011)$ in various other books he wrote, often in collaboration with Mimi Sheller (2004, 2006). 
Mobile culture is an emerging paradigm in current mobile societies, where processes, capitals, actors and things, and the nature of culture, are in continuous movement and transformation. Mobile culture is a recent means of enjoying and knowing cultural heritage, linked to the mobilities and discourses on the urban. Today, in the public space of streets, museums and galleries, citizens, tourists and various social marginalities operate multimodal strategies of urban cultural communication, often based on digital media like mobile phones, aimed at knowing and enjoying tangible heritage (monuments, artworks, cinema/video) and intangible heritage (music, cultural e-heritage). In other words, we are seeing the emergence of a mobile cyberspace and cybertime. Cybertime is the set of social temporalities (or courses) operated by the user of social spatialities (trajectories) on the public cyberspace of the Internet, resident on servers or mobilised by mobile devices.

Returning to the distinction made in the introduction between methodology and methods, an interesting discussion exists today on sociocultural mobilities and their sociological interpretation. On the one hand, concerning those mobile cultures underlying cultural and artistic tourism (Hanna, 2015; Kaminski, 2014). On the other, as regards the mobilities relating to the processes and instruments of research, especially in relation to research that uses mobile digital devices and which at times found a mobile scientific culture.

Epistemology, theory and innovative methodologies were debated within the fields of these urban and digital mobilities. In fact, Colin Hall (2005) drew attention to the need to reconsider the epistemological foundations of the sociology of mobilities. The researcher can be seen as a scientific traveller between different social contexts besides the academic world (Slocum, 2015). In this view, research strategies in themselves, and qualitative methodology in particular, have undergone irreversible transformations, such as unprecedented interlinking between more classical epistemologies and methodologies, on the one hand, and so-called ontologies, on the other, in recent essays in the social and human sciences. Ontologies are nothing more than sets of concepts linked by specific relationships, representing logical and dialectical propositions that delimit a given area of knowledge, in particular by means of digital resources and instruments.

In particular, the relationship between travel and innovation has been seen as key in the social sciences (Hall, 2008). The very epistemological status of urban and digital travel and mobilities is called into question by the innovative concept of slow travel, a form of mobility that aims to understand, deeply and at a more meditative pace, the identities and differences between the world's peoples and cultures, at both a global and local level (Fullagar, 2012).

Other important writers and books who have analysed this issue include Bruno Latour et al who laid the groundwork for the actor-network theory. This is a reflexive theory closely connected to the modus operandi. It was first applied to academic or experimental empirical areas such as the scientific laboratory, but it was also used to understand social relations in wider reticular contexts, for example within digital social networks. The theory was also linked to the question of mobile cultures, especially tourism (Duim, 
2012). The mobility behaviour and corresponding psychology of tourists is also related to the respective sustainability of urban policies (Cohen, 2014). Other innovative methods include mobile methods, such as where the researcher uses a laptop or mobile phone (Buscher, 2011), or visual research methods, in the case of tourism (Rakic, 2012).

Finally, with regard to empirical fieldwork, one cannot overemphasise that we are immersed in a mobile world, both as social agents and researchers, as Jennie Molz (2014) stresses. Our daily lives as citizens, tourists or any another condition and state of mobility are mobile (Elliot \& Urry, 2010). In fact, on our planet, there are myriad forms of mobility, such as the intercultural sharing perpetrated by tourists (Barker, 2014), but also the dramatic diasporas of immigrants, re-localisations that require new and innovative policies of place (Verstrate, 2009). In this context of accelerated change, if the social scientist wants to follow the trail of other social agents rigorously, they will also have to apply the so-called mobile city technologies in their research (Scheller \& Urry, 2006). Under these circumstances, the very nature of scientific fieldwork starts to metamorphosise (Hall, 2011).

Moreover, the "mobile cultures" concept is rooted in research on urban cultures and tourism begun in 1979-80 by the author of this paper. This research was disseminated and published, on the one hand, in books on the mass tourism of the Grupos Excursionistas e Almoçaristas/Jantaristas (Andrade, 1981, 1986). On the other hand, the research produced the concepts of "inter-travel" (a hybridisation of various types of travel: tourism, professional, political, religious, etc.); "critical tourism" (an anti-mass tourism attitude by tourists) and "counter-tourism" (the vision of an alternative world to that of local folk cultures by the native residents of societies visited by tourists).

These and other results were synthesised in the proposed creation, by the author of this paper, of a sociological genre called "semantic-logical sociology" (Andrade, 2011a, 2011b). This interpretative paradigm of society, amongst other pedestals, is forged in the tsunami of knowledge mobilised by new media, cyberspace technologies and mobile devices. In fact, sociology is undergoing a revolution at the epistemological, theoretical and methodological levels, based on the urban networks of the global metropolis connected to the social and semantic networks underlying the Social Web or Web 2.0 (Facebook, Twitter, Instagram, What's App) and the Social-Semantic Web or Web 3.0 (Freebase, Google, Wikipedia). For this desideratum, sociologists can use the GeoNeologic method, which consists of analysing and interpreting social processes in three dimensions: space (hence the prefix "geo"'); time, above all the rhythms of innovation ("neo"); and logos, a concept signifying the language of reason, or the reason of language, heard, spoken or written by social subjects. This trichotomy is inspired by the concept of deixis from Greek philosophy but applied to the social arena.

This analysis was recently perfected in an essay on "cultural e-tourism", i.e. tourism that takes place in urban, cultural and digital networks. Citizens, tourists and immigrants represent and present their own work, leisure and knowledge travels via the discourse produced and reproduced by their own journeys, mobilities and the respective descriptions, narratives and opinions, within the fabric of the city and on "cultural e-heritage" networks (Andrade, 2017). 
Today, mobile phones offers apps that include augmented reality for profiles of consumers such as young people, tourists and social marginalities: i.e. they present real locations in images, video or $3 \mathrm{D}$, and information about them in real time. This trend inaugurates an augmented urban and tourism culture where the reality of leisure time is boosted by the link between entertainment shows, relevant information about places visited and cultural events. The cities of Braga (in Portugal) and the Northeast have kept abreast of these smart development strategies for mobile culture, such as Braga's connection with the Unesco Creative City Network and Smart City. Additionally, within the framework of risk societies, a term suggested by Ulrick Beck (1992), it is important to reflect on risks such as the fetishism of digital urban culture and the reification of the tourism market; or their potential, for example more intense inter/transcultural exchange in cities and better knowledge of the societies that tourists visit.

\section{A STRATEGY FOR STUDYING MOBILE URBAN AND TOURISM COMMUNICATION}

Urban visibility or invisibility are communicative processes that occur at the contextual level of the mediated city. This intermediation interlinks two levels of society. On the one hand, the visions of the world that circulate within the city, according to the social structures of the urban agents, such as age, gender, social class, ethnicity, educational level, etc.. On the other hand, the microscopic social visualities inherent to daily life (Andrade, 1995, 1997a, 1997b).

This question of the urban (in)visible is of special relevance within the framework of urban mobilities, and particularly mobile urban and tourism communication, for example in the case of cultural tourists visiting certain urban locations, such as museums and art galleries, with specific underlying modes of communication. The "Mobile Culture and Tourism Communication" project has been trying to extend this process since February $2017^{\prime}$.

The metropolitan (in)visibilities shared by the Mobile Culture project and the advertising of some of the activities at the NewArtFest'17 Exhibition, examined below, whether of a citizen, tourism or migrant nature, is based on an intervention that is not just theoretical but also practical and participatory on the urban fabric. This collective action is known as artistic sociology and avant-garde virtual digital arts, but it also operates as a vehicle for sharing cultural experiences in today's intercultural and transcultural world.

\section{Artistic SOCIOLOGY AND THE HYBRID MONUment}

A hybrid monument is a building which fuses various monuments to celebrate a cultural heritage that is both separate yet common. It can help citizens, tourists and immigrants to understand local or global cultural heritage within a transcultural strategy. Transcultural means the transformation of culture into knowledge, particularly in the contexts of City 3.0 and Tourism 3.0, ideas discussed in the following section of this paper.

"The "Mobile Culture and Tourism Communication" project brings together a team coordinated by the author of this article at the Communication and Society Research Centre of the University of Minho in Braga, Portugal. 
The Tower of Belém in Lisbon and the Eiffel Tower in Paris are two notable urban cultural and tourism icons. By hybridising them, they become an exciting example of a hybrid monument (Figure 1).

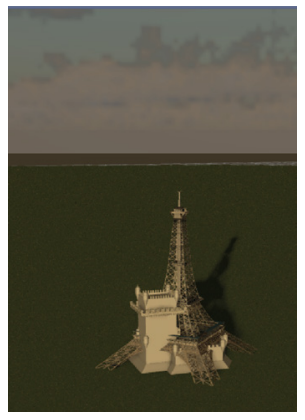

Figure 1: A hybrid monument

In fact, they are not exactly twin towers, but they are testimony to a common process of cultural inheritance. The Tower of Belém is a metaphor for a ship, a celebration of the Portuguese voyages of discovery in the $16^{\text {th }}$ century that Immanuel Wallerstein (2011) suggests began the process of globalisation. The Eiffel Tower is the symbol of another period of globalisation, the $19^{\text {th }}$ century industrial revolution. However, the hybridisation of these two different, yet very similar, towers tells us that we must differentiate and connect all the cultures of the world dialogically, democratically and equally.

After all, hybridology is also defined as the study of the entities of an intercultural and transcultural world. In fact, hybridology uses hybrimedia, i.e. a medium that transforms original media (those at the start of a given process), such as the building medium (exemplified here by the Tower of Belém and the Eiffel Tower), into original or innovative media (a hybrid building medium, illustrated here by the hybrid monument).

\section{TOURISM 3.0 AND CitY 3.0}

Various theoretical positions suggest what actually constitutes the phenomena of Tourism 3.0 allied to the context of City 3.0.

Greg Richards (2011) defines Tourism 3.0 according to these attributes: the greater interest by tourists in intangible heritage; the overcoming of the dichotomy between high and popular culture, witnessed for example by tourists' interest in the street; the hybridisation between cultural production and consumption; and the desire for authentic experiences. This author relates Tourism 3.0 to so-called Culture 3.0 (Sacco, 2011), with which it shares characteristics. Besides seeing culture as a product derived from the 18th and 20th-century industrial economy (Culture 1.0), or the idea of culture as a cultural industry in the $20^{\text {th }}$ century (Culture 2.0), the notion of Culture 3.0, associated with the new digital technologies, means that culture is a means of creating identity and values, stimulating social cohesion and incentivising creativity. John Urry himself, as mentioned earlier, updated the 2009 edition of the classic The Tourist Gaze to The Tourist Gaze 3.0 in 2011. 
However, in my opinion, to define Tourism 3.0 and City 3.0, these positions do not take various complex phenomena inherent to urban social networks sufficiently into consideration, such as those underlying the digital social networks characteristic of Web 2.0 and Web 3.0 (Andrade, 2011b), notions that we shall clarify below.

Firstly, the tourist, when visiting any destination, not only gathers information about the place visited, but also knowledge and flavours that are characteristic of them (Andrade, 1992). In fact, any location is founded on and fused with local social networks, inside their physical and geographical space and time. One example is the Portuguese tavern. In this space and time, local flavours (food, drink, etc.) are enjoyed alongside local knowledge (habits, values, traditions, innovations, etc.). These urban social networks include everyday and collective people, objects, spaces and time.

Secondly, mass tourism is today supported via digital social networks, a new paradigm in relation to pre-modern and locative social networks, which have recently been transformed into global social networks.

These digital social networks are not just organised in cyberspace but also in cybertime. It should be remembered that this concept means the number of steps taken in the networks of virtual public space, and occurred through certain tempos in digital public time.

In the 1990s, internet users could read information but almost could not write it, their participation being somewhat limited. This communication model is called Web 1.0.

Since the 2000s, Internet explorers have been able to read and write more in-depth and current information, in more participatory ways. This was the origin of Web 2.0 or the Social Web (Facebook, Twitter, Instagram, etc.), whereby citizens and tourists have been using mobile devices extensively and intensively for several years.

In the 2010s, Web 3.0 or the social semantic web emerged, whereby on websites, blogs, wikis and Web 3.0 networks opinions and interpretations on the information in circulation are shared, to a greater extent than on Web 2.0. In other words, besides the social network, Web 3.0 is a semantic network, insofar as it offers meanings on the actions and words spoken by its users in reticular connection. Some pioneering examples are Wikipedia and wikis in general, and the Freebase project, recently taken over by Google.

At first, residents and tourists, and even immigrants and other social marginalities, discover that society is a $S O(C) I T Y$, i.e. a social city. This social city means that the urban space can be enjoyed through art and reflection on the daily life of its inhabitants and visitors. This enjoyment of urban leisure space and time by local and global citizens today is often conducted through mobile devices like the mobile phone.

These mobile devices are veritable pocket computers that provide more than just information. Secondly, they also allow incommensurable knowledge about the societies and cultures visited, as well as about their visitors, to be shared.

In other words, the city becomes a City 3.0 or social semantic city, i.e. that globalised place whose ultimate current meaning is as follows: a geographical urban network which uses the digital, social and also semantic networks characteristic of Web 3.0, particularly in the activities of Tourism 3.0. 


\section{ARTISTIC SOCIOLOGY: AN INNOVATIVE EPISTEMOLOGICAL AND METHODOLOGICAL CONFIGURATION?}

Next, we will try to apply the previous considerations to the extension activities included in the aforementioned "Mobile Culture and Tourism Communication" project by using various sociological approaches, digital technologies and artistic strategies. The sociological content referred to below, and included in Appendix 1 to 4, was shown at the NewArtFest'17 digital art event in the hybrid form of the methodology circumscribed above as artistic sociology in the "Artistic Sociology and Hybridology" section. We must remember that a methodology can be partly perceived as a problematisation grid or a grammar of methods and techniques. As we shall see, this methodology circumscribes the Sociological Exhibition method, which in turns includes three techniques: sociological comics; the virtual visual survey; and the virtual sociological gallery.

These ideas are shown briefly in Appendix 2, 3 and 4, and in two simple pedagogical forms intended for students, teachers and researchers, amongst other audiences. On the one hand, the descriptive sheets of each work art, besides having been used to organize the NewArtFest'17 event, allow the succinct definition of social and sociological content, and show empirically how you draft a technical descriptive sheet for the purposes of managing or enlivening exhibitions, for extensive activities in museums, art galleries or other urban public spaces. On the other, the illustrations supply a more iconic perspective of the rationalities and sensibilities involved both in the citizen's experience of urban and tourism cultures and the sociologist's interpretation and explanation of them.

In terms of the empirical field and fieldwork conducted within the framework of artistic sociology, it may be here that some innovation may be credited to this paper. On the one hand, original techniques are used, such as sociological comics and new technologies such as augmented reality in the virtual visual sociological gallery technique. These are attempts to open up sociological writing up to new media and argumentative resources that are more active and seductive for expressing and developing scientific, technological and artistic literacy by the researcher and teacher.

On the other hand, the aim is to raise awareness amongst citizens, tourists and urban marginalities of the need to use sociology as a means and a medium to understand their daily life, and thus transform them into research audiences. In this aspect, it is key to extend and understand the practices and opinions of these audiences with regard to the presentation and exposure of sociological material in unusual fields, such as museums and art galleries, or other public places, e.g. the street and urban walls, which also function as palimpsests of academic knowledge, but in close and sound dialogue with common knowledge. Perhaps it will thereby be possible to contribute to analysing social and sociological issues in a more interesting and participatory manner, test hypotheses in a broader and more convincing fashion, and disseminate ongoing research to a wider audience beyond the academic world. 


\section{The Sociological Exhibition MeTHod}

Using the Sociological Exhibition method, various audience profiles were filmed by the sociologist, which commented, discussed, appreciated or criticised content, objects of study and sociological methods in an environment beyond the university while exposed to visual arts, as if they were art objects. This device, simultaneously discursive and counter-discursive, calls into question not just some traditional pedagogical methods, such as the mere use of Powerpoint presentations in class, but also research methodology and the art exhibition itself. In these pedagogical and plural research domains, these processes should be more deeply hybridised, as in other alternative spaces and times.

\section{THE SOCIOLOGICAL COMIC TECHNIQUE}

This technique attempts, by means of a story, to express: (a) the knowledge implemented by institutions located in the communicative, democratic and digital contemporary city, such as academia; (b) and, on the other hand, the knowledge produced by urban digital citizens. And it does so by using the particular method of comics. However, social issues are not only understood and used as a substantive theme to propel this "sociological story". They are also immersed in the very mode of representing and presenting real or imaginary worlds. For example, social problems may not just be narrated but also analysed by means of a sociological search that uses visual and textual arguments inside comic book panels (see Technical Sheet 1 and Figures 4 to 10).

\section{THE VIRTUAL-VISUAL SURVEY TECHNIQUE}

The second technique used by artistic sociology aims to overcome some of the disadvantages of the sociological survey, such as the somewhat routine and scarcely motivating traditional questionnaire, in the way it is directly and indirectly conducted. For that reason, a virtual-visual survey on $2 \mathrm{D}$ animated video was developed that included a central question on the economic, political and cultural situation of our global/local and transcultural network societies (see Technical Sheet 2 and Figures 12 to 19)

\section{THE VIRTUAL SOCIOLOGICAL GALLERY TECHNIQUE}

Finally, the third technique applies recent digital technologies to sociological research. Edmund Husserl (1975) limits the phenomenological process to three key stages: perception, consciousness and knowledge of reality. With regard to knowledge, in the framework of a genealogy of logic, it analyses the pre-predicative experience, the structure of predicative thought and the origin of conceptual thought. Alfred Schultz (1967) adapts Husserl's phenomenology to social reality, establishing the grounds and pedestals of the action of the participatory citizen in the worlds of everyday life (lebenwelt).

In the case of the virtual sociological gallery, hybrid reality consists of a mode of experience, consciousness and unprecedented knowledge of urban cultural reality. In 
fact, virtual sociological gallery hybridises the real reality of exhibition visitors, to its interpretative modes and logic mobilised by the social scientist, for example virtual reality (immersion in $3 \mathrm{D}$ virtual world) and augmented reality (experience of a an $3 \mathrm{D}$ virtual world with added textual, statistical, geographical and other information in real time). The epistemological and methodological consequences for education and innovative sociological research are decisive.

For example, it is possible to enliven a class on cultural heritage and tourism by presenting sources and debates using mobile devices and augmented reality apps. Or by using hardware and software to compile, analyse, interpret and disseminate content in research projects, not just in an academic context, but also in urban places of culture where the citizen and tourist share their daily itineraries, amidst an intercultural and hybrid dialogue (see Appendix 4, Technical Sheet 3 and Figures 20 to 23).

\section{Conclusion}

By way of a final conclusion, let us return to some of the questions raised in this paper, in order to propose suggestions for an urgent discussion and debate.

In terms of the results, which are always provisional in a mobile field such as the one that we propose to address herein, and with regard to the sense of epistemological disquiet mentioned in the Introduction, it seems to us that Hybridology (i.e. the study of hybrid entities by means of hybrid knowledge), will become one of the most pressing arenas of discussion over coming years. For example, this will apply to some of the problems in the field of inter-culturalism and trans-culturalism, such as the media discourse on social agents who are perceived to be "hybrid", whether returnees, immigrants or refugees (Marinho, 2015). At the level of theoretical reflection in the sociological field, the concepts of "mobile culture" and "urban and tourist communication" will probably be viewed as two cornerstones of Communication and New Media Sociologies. At the level of methodologies, the Sociology of Art, as outlined above, will establish one of the possible and probable cross-breeding grounds between rational knowledge and sensible wisdom.

With regard to the pitfalls and limitations of research, this journey towards knowledge will certainly entail uncertainties. However, sociological writing involves inherent social, professional, epistemological and sociological risks.

In relation to improvements that it may be possible to attain in the future, such a strategy will only be possible through dialogue and sharing of at least three modes of knowledge: scientific knowledge; the professional knowledge of mediating institutions, such as the museum; and the common or ordinary knowledge of a new research audience that will gradually emerge in urban and digital social networks, including the following social agents: from the outset citizens and tourists, and also the various marginal social groups including, among others: pensioners, persons with disabilities, immigrants, and ethnic, political, religious and gender-based minorities.

Finally, as far as future steps are concerned, all writers and readers of the Social and Human Sciences, knowledgeable people and research audiences must participate 
in this, and other necessary, collective debates, where the difficulties and successes, innovations and repetitions, are intertwined in hitherto unseen solidarity-based social, scientific, technological and artistic networks that aim to produce, interpret and disseminate hybrid knowledge, without any definite certainties. Ultimately we're all, to a greater or lesser extent, citizens, tourists and immigrants of the scientific, technological and artistic knowledge, who aim to be critical, and at some scale, however small, also be innovators.

Translated by Martin Dale (Formigueiro, Conteúdos Digitais, Lda)

\section{BIOGRAPHICAL NOTE}

Pedro Andrade is a Researcher at the University of Minho and has a PhD in Cultural Sociology from FCSH-Universidade Nova, Lisbon. He has taught Sociology at the Universities of Coimbra, Lisbon and Minho. Areas: Sociology, Visual Arts / Cinema, Communication / Social Networks, Methodologies and Hypermedia. Coordinator of projects funded by the FCT: "Scientific-Technological Literacy and Public Opinion: the case of Science Museums"; "Public Communication of the Arts: the case of Local / Global Art Museums". As a member of the Paris Film Coop, he directed: Film Saboté Spatial and Cinéma Corps. Hypermedia / hybrid works: $1^{\text {st }}$ Portuguese cultural webpage (1995). Sociological Games (2006). Hybrid Blog (2006). Novela GeoNeoLógica (2009). Social-Semantic Sites in Web 2.0 and Web 3.0 Networks (2011). Sociological Comic Strips (2013/2016).

E-mail: pjoandrade@gmail.com

Address: Calçada dos Mestres, 7, $4^{\circ}$ B, 1070-176 Lisbon

Communication and Society Research Centre. Campus de Gualtar. 4710-057 Braga, Portugal

\section{BibLIOGRAPHIC REFERENCES}

Andrade, P. (1979). A taberna. Arte-Opinião, 6, 13-16.

Andrade, P. (1981). Les groupes 'excursionistes'-'de déjeuners' portugais et leur art. Paris: École des Hautes Études en Sciences Sociales.

Andrade, P. (1986). A arte excursionista. Colóquio-Artes, 68, 5-11.

Andrade, P. (1987). Alvarez, pintor dionisíaco. Colóquio-Artes, 74, 20-25.

Andrade, P. (1988). O beber e a tasca: práticas tabernais em corpo vínico. Povos e Culturas, 2, 223-263.

Andrade, P. (1991). A taberna mediática, local reticular de negociações sociais e sociológicas. Revista Crítica de Ciências Sociais, 33, 265-286.

Andrade, P. (1992, February 5). A taberna e o beber, seus sabores e saberes. Correio das Regiões, p. 6.

Andrade, P. (1995a). Editorial português. Atalaia, 1/2, 15-21. 
Andrade, P. (1995b). A negociação do visível: as visibilidades sociais enquanto objecto teórico ilustrativo da Sociologia interdimensional e mediadora-I. Atalaia, 1/2, 73-93.

Andrade, P. (1997a). A negociação do visível-II: o tempo das visibilidades sociais e as visões da natureza. Atalaia, 3, 143-151.

Andrade, P. (1997b). Sociologia do olhar: um novo olhar sobre a sociologia? Atalaia, 3, 197-201.

Andrade, P. (2011a). Sociologia semântico-lógica da web 2.0/3.o na sociedade da investigação: significados e discursos quotidianos em blogs, wikis, mundos/museus virtuais e redes sociais semântico-lógicas. Lisboa: Edições Caleidoscópio.

Andrade, P. (2011b, february).Tourism imaginaries and web 3.0: a quest of meaning at the art museum. Paper presented at congresso International Conference Tourism Imaginaries, Berkeley, University of California.

Andrade, P. (2014). Post-colonial co-ordinary literature and web 2.0/3.0: thinking back within transmediatic knowledge. In M. Pope (Ed.), New literary hybrids in the age of multimedia expression: crossing borders, crossing genres (pp. 123-144). Amsterdam/Philadelphia: John Benjamins Publishing.

Andrade, P. (2015). Hybridologie. In M. Veyrat (Ed.), 110 Notions sur les Arts Numériques (pp. 179-80). Paris: Les Éditions de l'Immatériel.

Andrade, P. (2017). Cultural e-tourism depicted by digital discourse: innovative mobilities at urban e-heritage networks. In M. Bielenia-Grajewska \& M. Ríos (Eds), Innovative perspectives on tourism discourse (pp. 1-17). Hershey: IGI Global.

Bakhtin, M. (1983). The dialogic imagination: four essays. Austin: University of Texas Press.

Barker, A. (2014). Identity and intercultural exchange in travel and tourism. Bristol: Channel View Publications.

Beck, U. (1992). Risk society: towards a new modernity. London: Sage.

Büscher, M. \& Urry, J. (2011). Mobile methods. London: Routledge.

Cohen, S. \& Higham, J. (Eds.) (2014) Understanding and governing sustainable tourism mobility: psychological and behavioural approaches. London: Routledge.

Dillman, D., Smyth, J. \& Christina, L. (2009). Internet, mail and mixed-mode surveys: thetailored design method. Hoboken: John Wiley \& Sons.

Duim, R., Ren, C. \& Johannesson, G. (Eds.) (2012). Actor-network theory and tourism: ordering, materiality and multiplicity. London: Routledge.

Elliott, A. \& Urry, J. (2010). Mobile lives. London: Routledge.

Fischer, H. (1977). Theorie de l'art sociologique. Paris: Casterman.

Flanagan, M. (2009). Critical play: radical game design. Cambridge, Massachussets: The MIT Press.

Forest, F. (1977). Art sociologique vidéo: dossier Fred Forest. Paris: UGE.

Fullagar, S., Markwell, K. \& Wilson, E. (Eds.). (2012). Slow travel and tourism: experiences and mobilities. Bristol: Channel View Publications.

Gleick, J. (2008). Chaos: making a new science. London: Penguin Books. 
Goodson, L. (Ed.) (2004). Qualitative research in tourism: ontologies, epistemologies and methodologies. London: Routledge.

Hall, C. \& Williams, A. (2008). Tourism and innovation. London: Routledge.

Hall, C. (2011). Fieldwork in tourism: methods, issues and reflections. London: Routledge.

Hall, C. (2005). Tourism: rethinking the social science of mobility. Upper Saddle River: Pearson/Prentice Hall.

Hanna, S., Potter, A., Modlin, E., Carter, P. \& Butler, L. (Eds.) (2015). Social memory and heritage tourism methodologies. London: Routledge.

Harper, D. (2012). Visual sociology. London: Routledge.

Husserl, E. (1975). Experience and judgment. Illinois: Northwestern University Press.

Kaminski, J., Benson, A. \& Arnold, D. (Eds). (2014). Contemporary issues in cultural heritage tourism. London: Routledge.

Kozinets, R. (2012). Netnography: doing ethnography research online. London: Sage.

Leavy, P. (2009). Method meets art: arts-based research practice. New York: The Guilford Press.

Marinho, S. (2015). Retornados e refugiados: as histórias dos media. In M. Pinto, S. Pereira \& M. J. Brites (Eds.), Os media e a crise dos refugiados: agenda de atividades (p. 9). Braga: CECS, Universidade do Minho.

Molz, J. (2014). Travel Connections: tourism, technology and togetherness in a mobile world. London: Routledge.

Paquette, G. (2010). Visual knowledge modelling for semantic web technologies: models and ontologies. New York: Hershey.

Pauwels, L. (2006). Representing moving cultures: expression, mutivocality, and reflexivity in anthropological and sociological filmaking. In Luc Pawels (Ed.), Visual cultures of science: rethinking representation practices iin knowledge building and science communication (pp. 120-152). Hanover: University Press of New England.

Pauwels, L. (2017). Reframing visual social science: towards a more visual sociology and anthropology. Cambridge: Cambridge University Press.

Pinto, M., Ribeiro, R. \& Durand, J. (2017)._Bugiada e mouriscada de Sobrado: a festa como património. In M. Menezes, J. Costa \& J. Rodrigues(Eds.), Intangibility matters. Proceedings IMaTTe 2017 International conference on the values of tangible heritage (pp. 83-84). Lisbon, May 29-30, 2017. LNEC: Lisboa.

Rakic, T. \& Chambers, D. (2012). An introduction to visual research methods in tourism. London: Routledge.

Richards, G. (2011). Creativity and tourism: the state of the art. Annals of Tourism Research, 38(4), $1225-1253$.

Rose, G. (2016). Visual methodologies: an introduction to researching with visual materials. London: Sage.

Sacco, P. (2011). Culture 3.0: a new perspective for the UE 2014-2020 structural funds programming. [Paper for the OCM Working Group on Cultural and Creative Industries, April 2011].

Sales, C. (2015). In the meantime or the (ab)use of online accessing during mobility. Comunicação $e$ Sociedade, 28, 229-251.

Schutz, A. (1967). Phenomenology of the social world. Illinois: Northwestern University Press. 
Sheller, M. \& Urry, J. (2004).Tourism mobilities: places to play, places in play. London: Routledge.

Sheller, M. \& Urry, J. (2006). Mobile technologies in the city. London: Routledge.

Slocum, S. \& Kline, C. (Eds.) (2015). Scientific tourism: researchers as travellers. London: Routledge.

Thenot, J. (2012). Petit traité d'existence à l'usage des jeunes artistes et des amateurs d'art. Grenoble: Critères Editions.

Urry, J. (2007). Mobilities. Cambridge: Polity Press.

Urry, J. \& Larsen, J. (2011). The tourist gaze 3.0. London: Sage.

Verstraete, G. (2009). Tracking Europe: mobility, diaspora, and the politics of location. Durham: Duke University Press.

Wallerstein, I. (2011). The modern world-system I: capitalist agriculture and the origins of the European world economy in the sixteenth century. California: University of California Press.

Zagalo, N. \& Branco, P. (2015). Creativity in the digital age. London: Springer London.

\section{* Submitted: 30.11 .2017 \\ * Accepted: 15.03.2018}

\section{Appendix 1: The eXHibition New ART Fest'17, as AN empirical Field For the PRESENTATION OF SOCIOLOGICAL METHODOLOGIES DEVELOPED IN THE MOBILE CULTURE AND TOURISM COMMUniCATION PROJECT (EXAMPLeS OF DISSEMINATION OF THE EVENT AND DIRECT OBSERVATION OF THE INAUGURATION OF THE EXHIBITION)}

In October and November 2017, in Lisbon, the first actions of the project "Mobile Culture and Tourism Communication" were co-organized, in addition to the previous planning work that had been conducted in Braga. The intention was twofold: on the one hand, to communicate to Portuguese citizens and visitors to the city of Lisbon (tourists, immigrants, etc.) a preview of the city, i.e. to visualise it before they look at the plurality of daily life in Lisbon and other cultural events); and also to disseminate a post-vision, i.e. a visual look after viewing the city in situ.

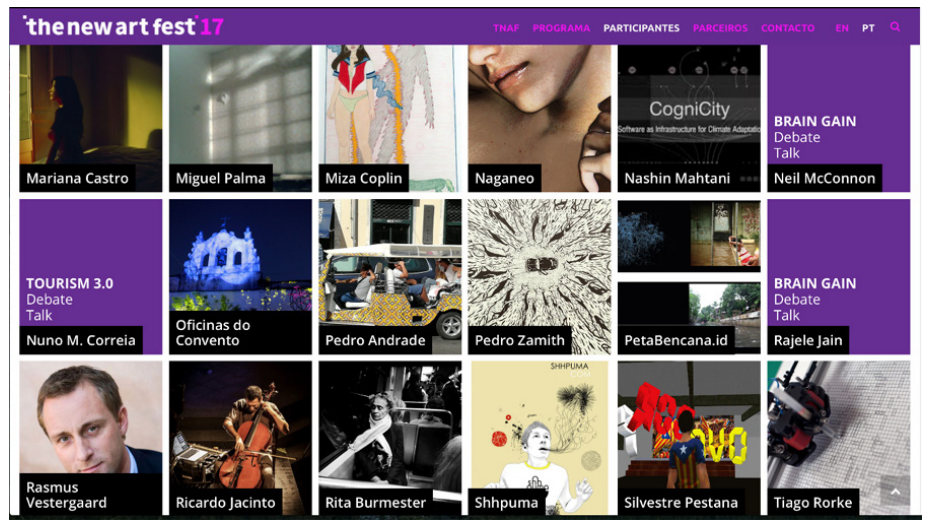

Figure 2: Programme and participating authors in the cultural event NewArtFest'17 (extract) 
The Mobile Culture project has exchanged several core themes with the event, revolving around the latest tourism and urban phenomena.

The website's mission statement said that the two main 'flavours' of the event are the social-semantic city (founded on urban and digital, social and semantic networks) and the 'GeoNeoLogical city', i.e. time and logos, a trichotomy which, as has been pointed out above, is based on the Greek word, deixis.
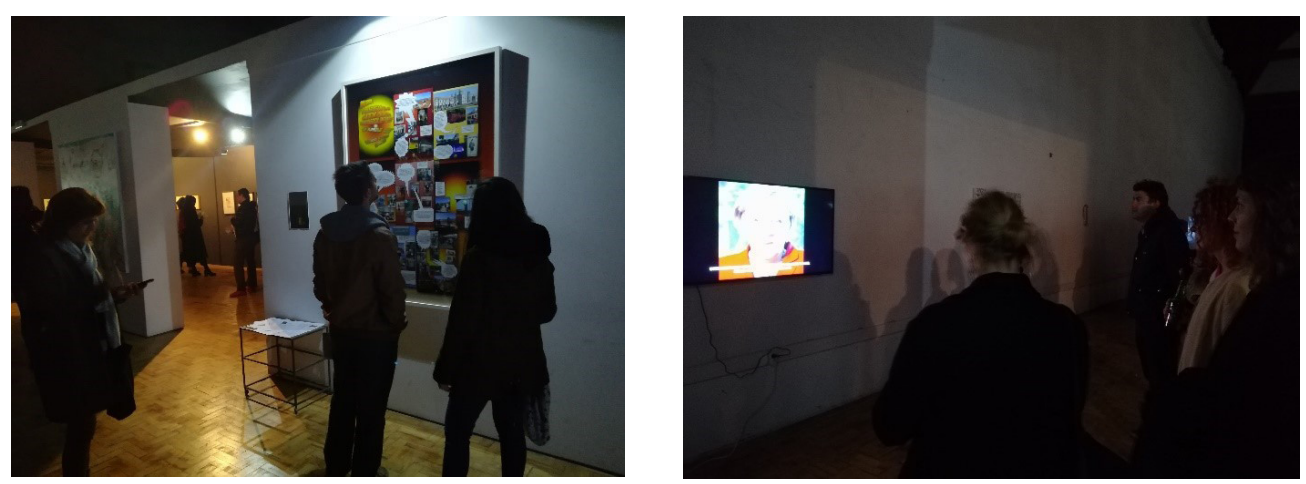

Figure 3: Audience viewing the works of the Sociological Exhibition and Virtual Sociological Gallery (top) and Virtual Survey (centre). Below, the author is talking with

the curators of the Natural History and Science Museum, the event's venue

Appendix 2: The method of the Sociological Exhibition applied to Tourism 3.0 / CITY 3.0 AND THE SOCIOLOGICAL COMIC STRIP TECHNIQUE

Technical sheet 1:

Title of the work: Sociological Exhibition on Tourism 3.0 / City 3.0: Mobile Art, from Artists to Tourists and Citizens

Year: 2017

Technique / Medium: Sociological Comic Strip, based on an assembly of photographs. Format: 2D

Dimension: $1,5 \times 1 \mathrm{~m}$.

Synopsis: this work of art is understood as a sociological exhibition about Tourism 3.0 in City 3.0. In particular, it clarifies the meaning of mobile art, in the context of contemporary social and semantic networks, activated by citizens and tourists. This art proposal constitutes a paratext, in the words of Gerard Genette. In other words, it is a set of contents that works as a business card or aperitif, for the presentation of other content, such as those included in other works of art by the same artist, for example the Virtual Survey and Virtual Sociological Gallery on City 3.0 / Tourism 3.0

Equipment needed for assembly and / or exhibition: assembly by the company X;

Specific requirements for assembly, transportation or other: transport by the company $\mathrm{X}$; 


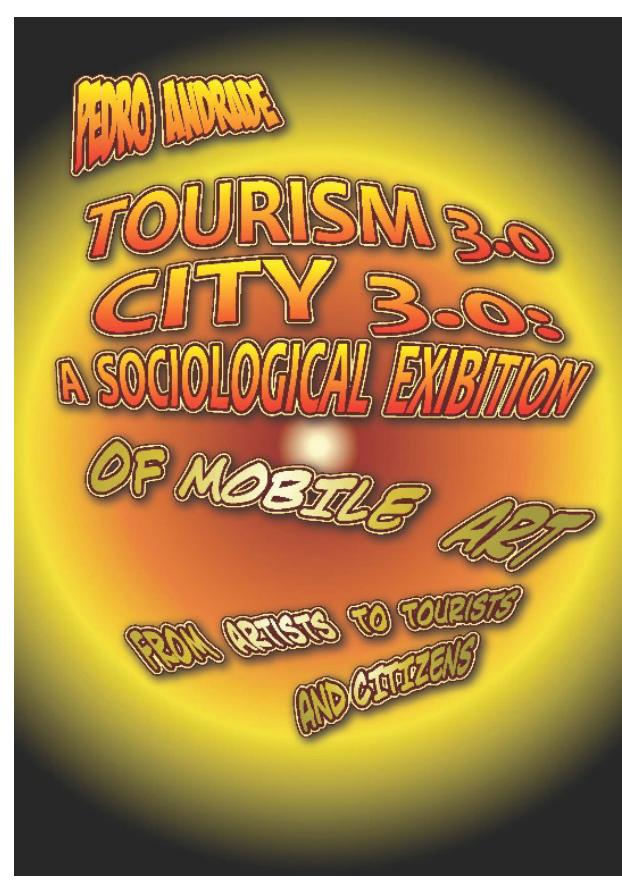

Figure 4: Sociological exhibition

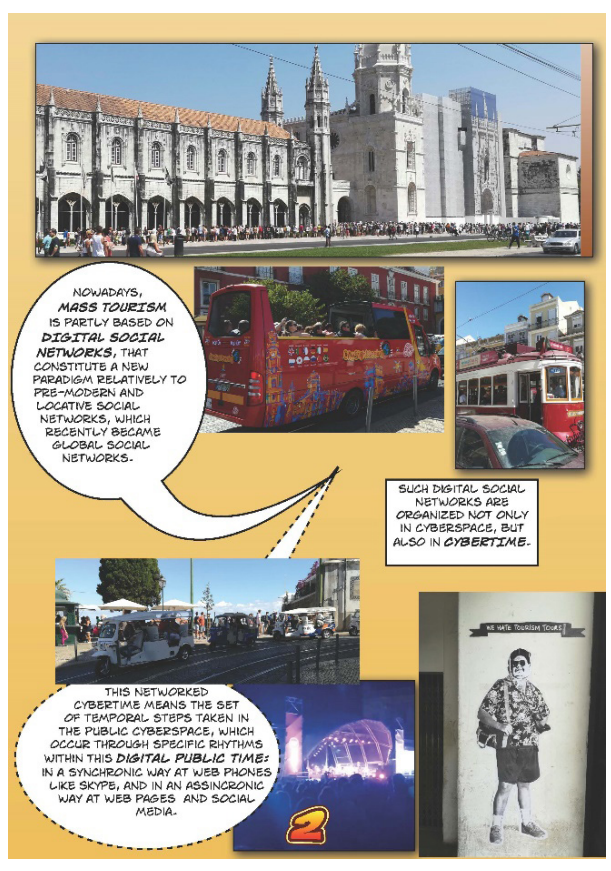

Figure 6: Mass tourism

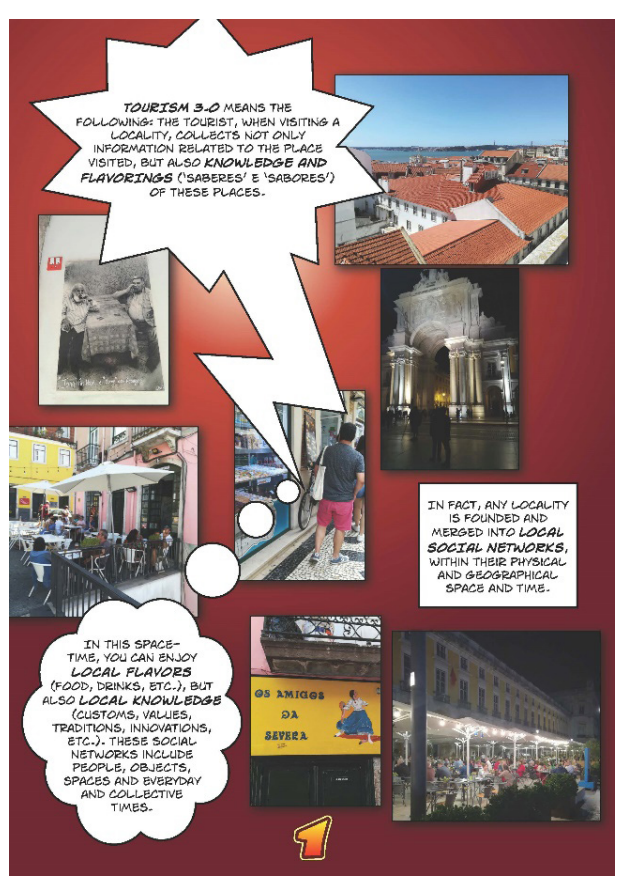

Figure 5: Tourism 3.0

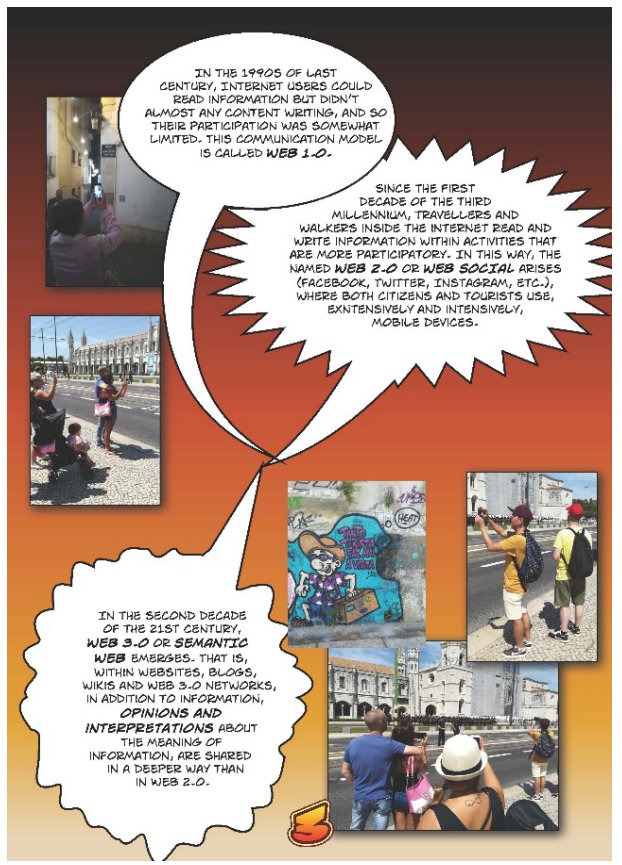

Figure 7: The three ages of the internet: Web 1.0, Web 2.0 and Web 3.0 


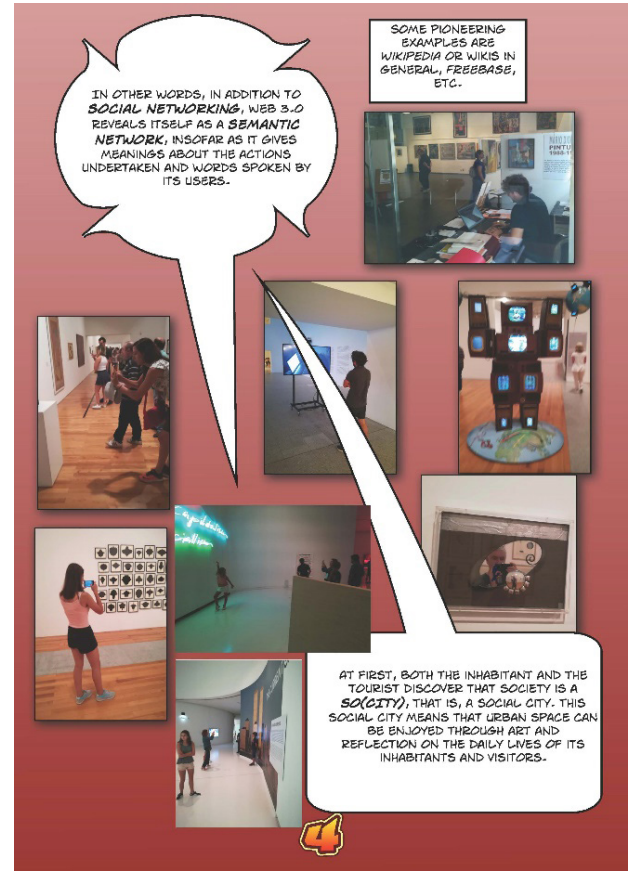

Figure 8: Society is a So(City)

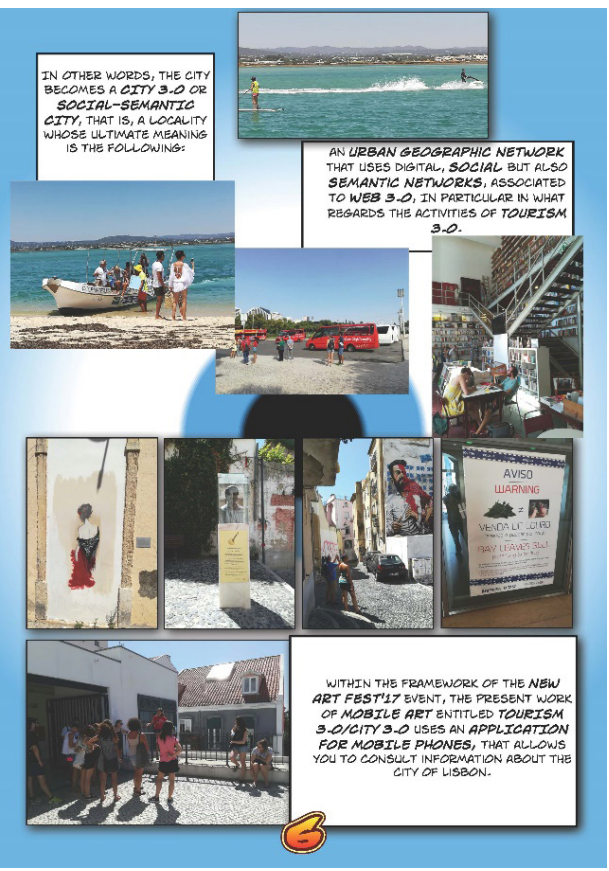

Figure 10. City 3.0, a socialsemantic network

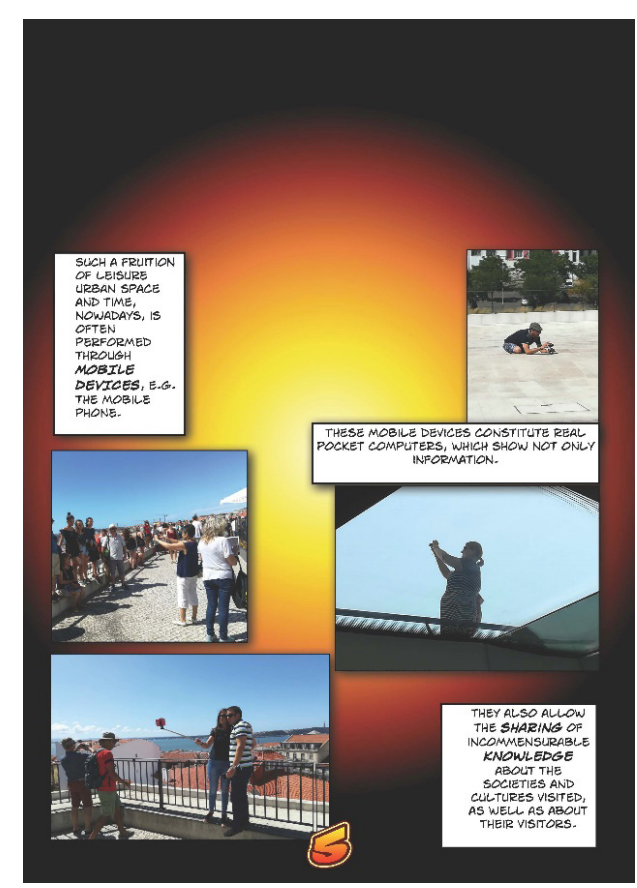

Figure 9: Mobile devices

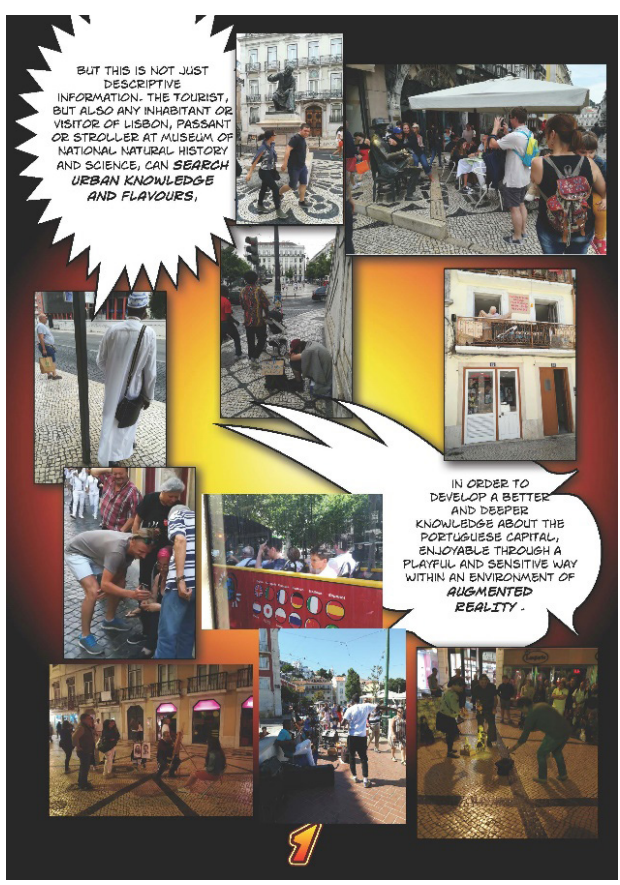

Figure 11: Hybrid Reality in the event NewArtFest' 177 


\section{APPENDIX 3: The VISUAL-VIRTUAL SURVEY TeChNIQUe on City 3.0 / TOURISM 3.0}

Technical sheet 2:

Title of the work: Visual-virtual survey on City 3.0 / Tourism 3.0

Year: 2017

Technique/Medium: Video

Format: 2D

Dimension: N.A.

Synopsis: The city and tourism 3.0 (or 'social-semantics') are based on a network of social meanings and singular semantic interpretations about the public space of daily life. This network is developed by the multiple agents who intervene in the urban fabric (local residents, tourists, immigrants, etc.). It is a 'geo-neo-logical' process. In other words, it takes place in a specific territory (hence the prefix 'geo'), in a period of continuous innovation (at a 'neo' rhythm), and implies different languages mobilized by urban actors. 'Logos' means the language or reason produced by social subjects.

A central question is posed to well-known politicians: what is the main transformation that affects contemporary cities and related phenomena, such as tourism and immigration?

Equipment needed for assembly and / or exhibition: video screen Specific requirements for assembly, transportation or other: N.A.

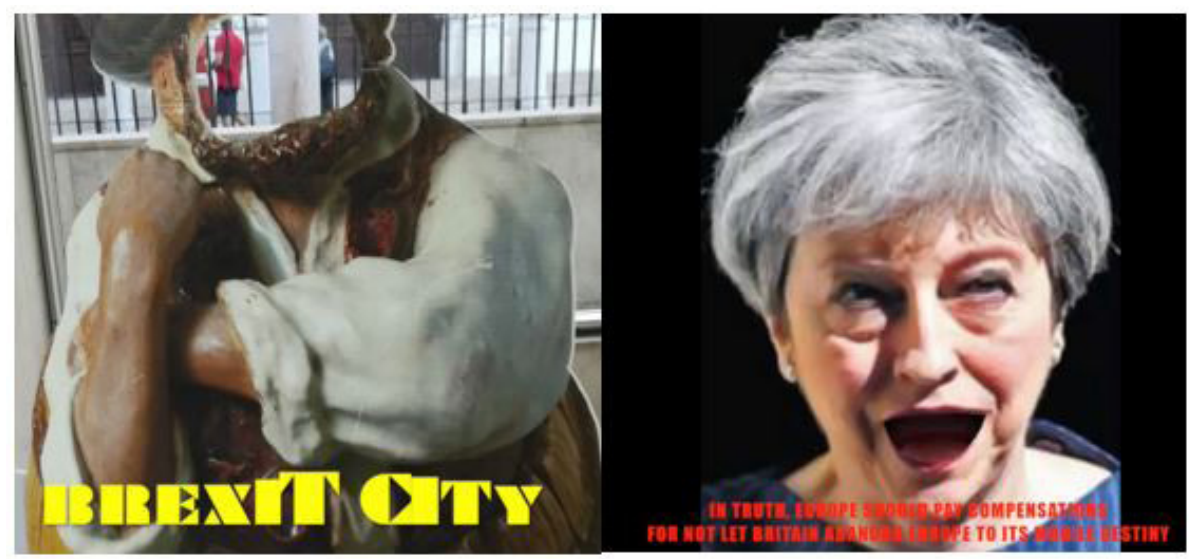

Figure 12

Text of the soundtrack and subtitles of the video: European countries need the United Kingdom more than the inverse, for city mobilities too. In truth, Europe should pay compensations for not letting Britain abandon Europe to its mobile destiny 


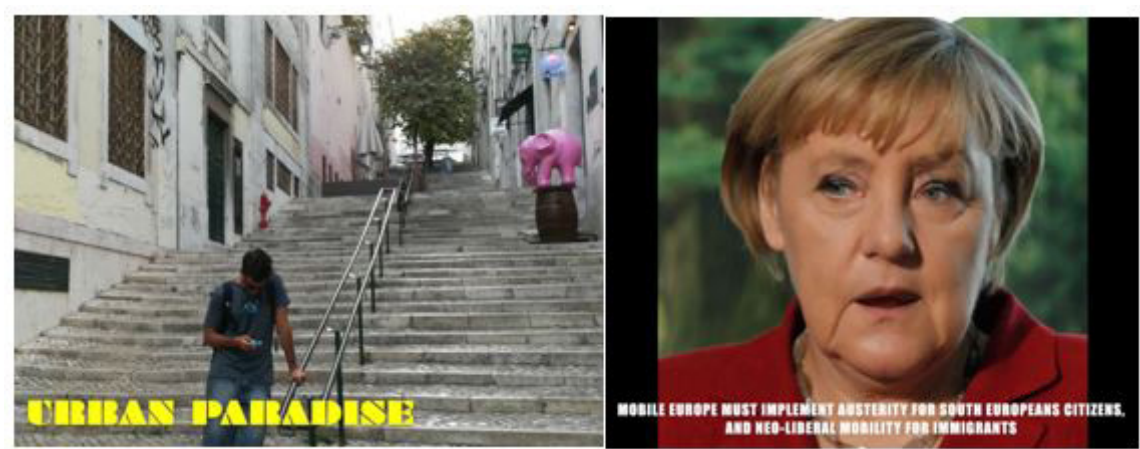

Figure 13

Text of the soundtrack and subtitles of the video: Mobile Europe must implement austerity for South European citizens, and neo-liberal mobility for immigrants

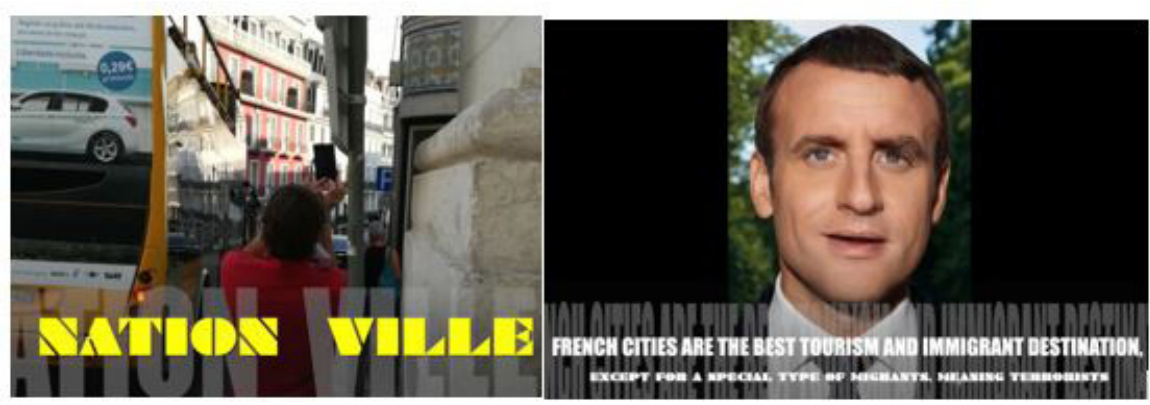

Figure 14

Text of the soundtrack and subtitles of the video: French cities are the best tourism and immigrant destination, except for a special type of migrants, meaning terrorists

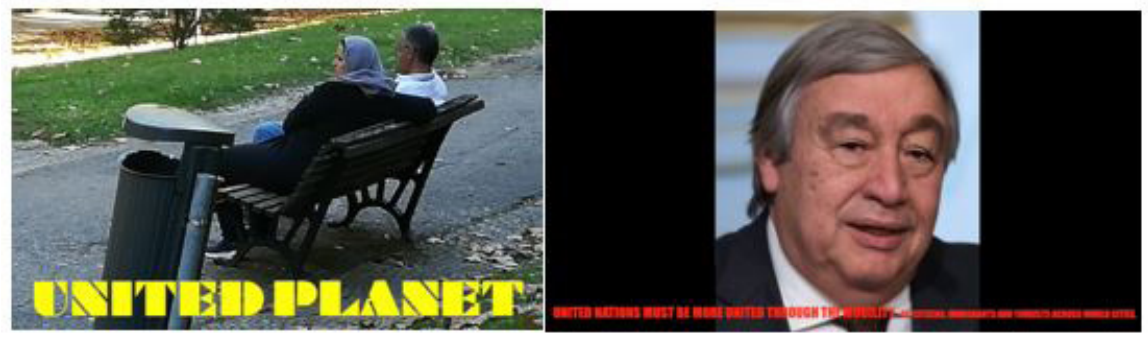

Figure 15

Text of the soundtrack and subtitles of the video: United Nations must be more united through the mobility of citizens, immigrants and tourists across world cities

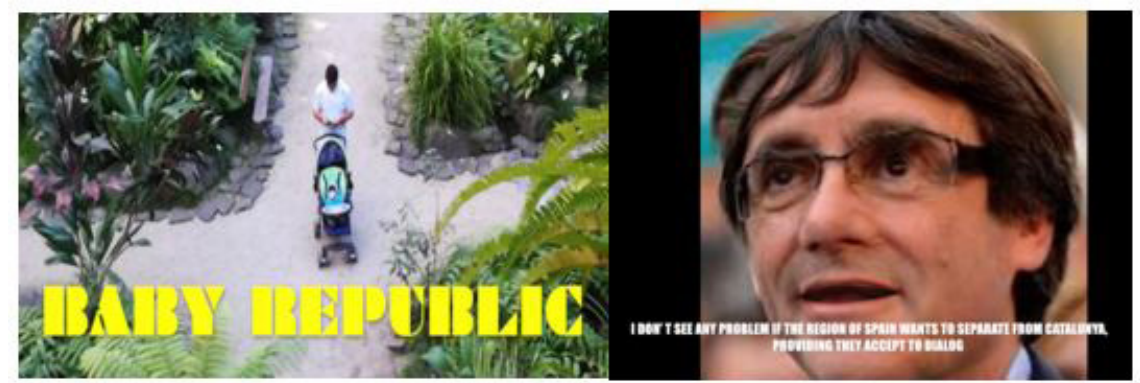

Figure 16

Text of the soundtrack and subtitles of the video: I don' $t$ see any problem if the region of Spain wants to separate from Catalonia, providing they accept to dialogue 


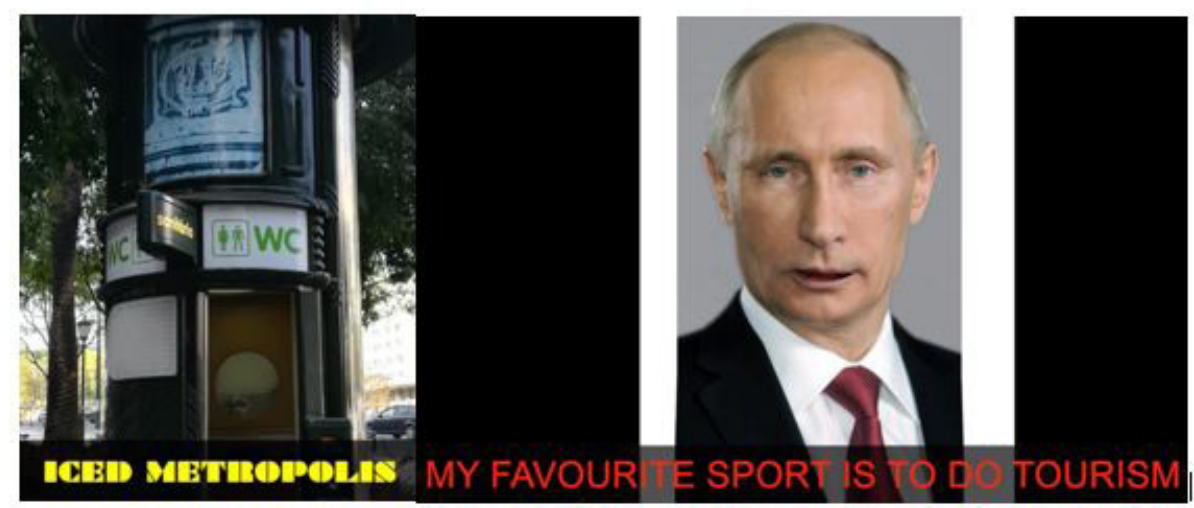

Figure 17

Text of the soundtrack and subtitles of the video: My favourite sport is tourism in the Crimea peninsula and Europe cities. Instead of cars, it is more practical to travel with tanks. Thanks, Europe...

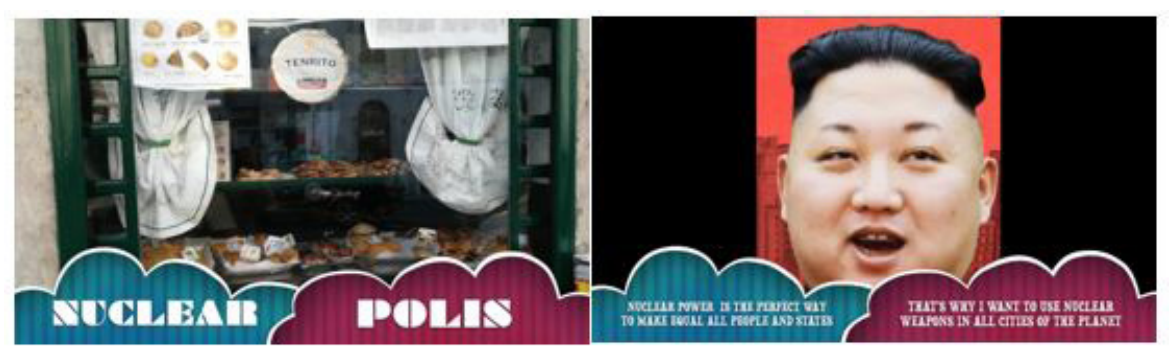

Figure 18

Text of the soundtrack and subtitles of the video: Nuclear power is the perfect way to make equal all people and states. That's why I want to use nuclear weapons in all cities of the planet...

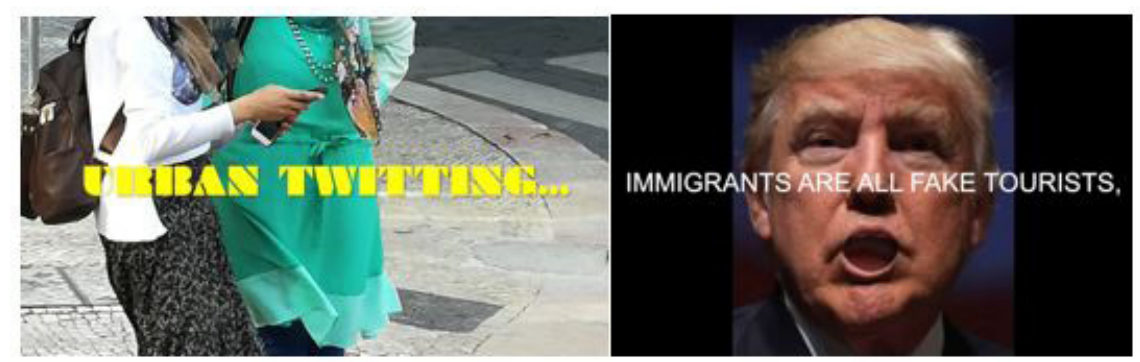

Figure 19

Text of the soundtrack and subtitles of the video: Immigrants are all fake tourists, and I am going to fire them all 


\section{Appendix 4: The Virtual Sociological Gallery technique on the City 3.0 /}

\section{TOURISM 3.0}

\section{Technical sheet 3:}

Title of the work: Virtual sociological gallery technique on the City 3.0 / Tourism 3.0

Year: 2017

Technique/Medium: Video, Augmented Reality, Hybrid Reality

Format: 2D and 3D.

Dimension: N.A.

Synopsis: this work of art organises content and knowledge about Lisbon and tourism in this city, through texts, images and socio-semantic sites within Web 3.o. When entering the application, the user can choose between the following links: Home: introduction to the exhibited content; About: CV of the author; Gallery: virtual exhibition of images of the Hybrid Monument; other links lead to social-semantic sites Experimental Books and Web 3 Novel, where there are various contents about the city, culture and tourism. The Hybrid Monument means a merger between the Tower of Belem in Lisbon and the Eiffel Tower, which operates a link between diverse cultural heritage. Here, it is queried through an augmented reality device. The visitor of the Virtual Sociological Gallery experiments with an unprecedented and seminal mix of social, virtual, augmented and mixed realities, in a process that produces Hybrid Reality.

Equipment needed for assembly and / or exhibition: mobile phone Specific requirements for assembly, transportation or other: N.A.

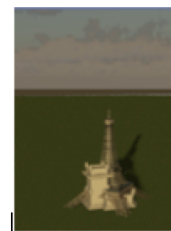

\section{thenew}

art fest 17

SOCIOLOGICAL VIRTUAL GALLERY

PEDRO ANDRADE @ 2017

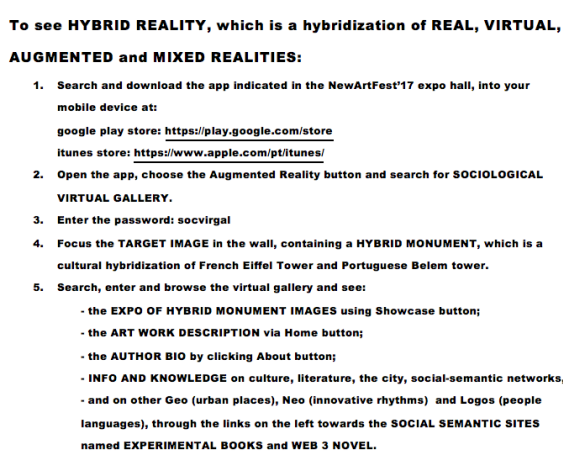

MEd EXPERIMENTAL BOOKS and WEB 3 NOVEL.

Figure 20: Room sheet in the exhibition 


\section{HYIBIRID MONOMBNT}

Dedro Andrade () 2001

A hybrid monument is a building that operates a fusion of several monuments, in order to celebrate a common cultural heritage. It may help citizens, tourists and migrants, to understand local or global cultural heritage, within a transcultural strategy. Transcultural means the transformation of culture into knowledge, within City 3.0 and Tourism 3.0 contexts.

Belem tower at Lisbon and Eiffel tower at Paris, are two notable cultural and tourist urban icons. Through their fusign, they constitute an example of a hybrid monument.

They aren't exactly twin towers, but they testify a common cultural heritage process. Belem Tower is a ship metaphor, to celebrate the Portuguese discoveries at the XVI century, which initiated the process of globalization. Eiffel Tower is a symbol of another globalization, the industrial revolution around the world at the XIX century. However, their hybridization adverts us that we must both differentiate and connect all world cultures, within a dialogic, democratic and equalitarian basis.

Figure 21: Destinations of the hyperlinks: Home: description of the Hybrid Monument

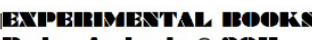

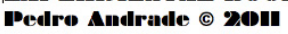

https://sites.google.com/site/livrosexperimentaisenglish/

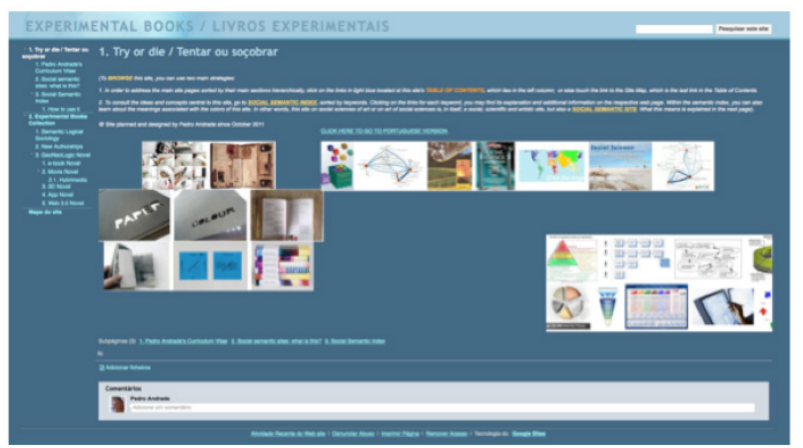

Figure 22: Destinations of the hyperlinks: site Experimental Books

WWBIS 83.9 NeDVBL

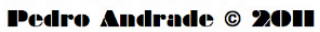

https://sites.google.com/site/weh3novelenglish/

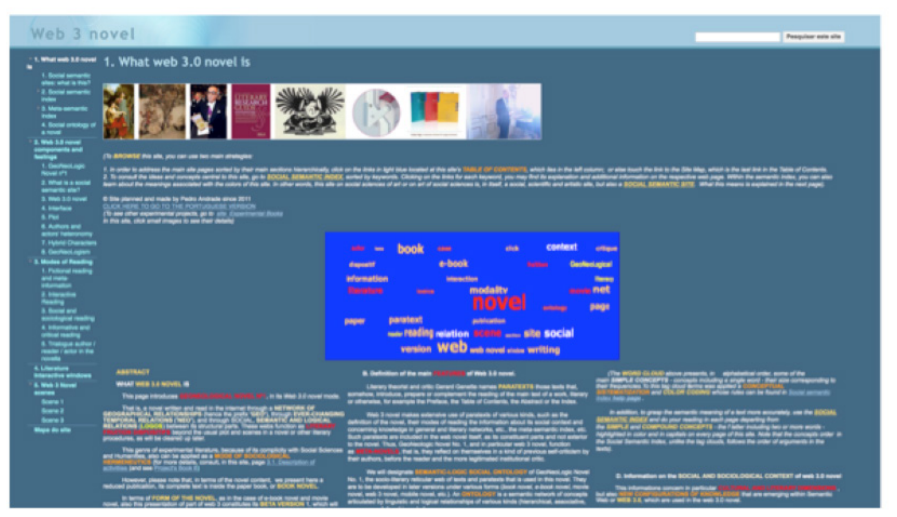

Figure 23: Destinations of the hyperlinks: site Web 3.0 Novel 